\title{
A survey of natural distribution of yellow tailflower mild mottle virus in south-western Australia reveals new indigenous and exotic hosts
}

\author{
Stephen Wylie ${ }^{1} \cdot$ Hua $\mathbf{L i}^{1}$
}

Received: 11 June 2017 / Accepted: 11 July 2017 /Published online: 2 August 2017

(C) Australasian Plant Pathology Society Inc. 2017

\begin{abstract}
Yellow tailflower mild mottle virus (YTMMV) was previously reported from two wild species of Anthocercis (family Solanaceae) in Western Australia. Here, a survey of 89 wild and cultivated plants from 14 species was done to determine if YTMMV occurred more widely in indigenous plants, and if it naturally infected cultivated exotic plants. The survey extended $1500 \mathrm{~km}$, from Coral Bay to Esperance, and revealed plants of nine solanaceous species to be naturally infected with YTMMV, including Capsicum annuum plants from a commercial planting.
\end{abstract}

Keywords Tobamovirus $\cdot$ Wild plant virus $\cdot$ Spillover

Yellow tailflower mild mottle virus (YTMMV), family Virgaviridae, genus Tobamovirus, was first reported in 2014 from a wild indigenous solanaceous plant of Anthocercis littoria (yellow tailflower) from the southwest of Western Australia (Wylie et al., 2014). It was subsequently discovered from a plant of A. ilicifolia subsp. Ilicifolia from the same region (Li et al., 2016). Its experimental host range comprised a wide range of solanaceous plants, including indigenous species, wild exotic weeds, and domesticated exotic species including tomato, capsicum and aubergine (Li et al., 2016). Symptoms of infection ranged from systemic necrosis in plants of Nicotiana benthamiana, to mildly symptomatic in Solanum lasiophyllum, both species indigenous to Western Australia. The mild

Stephen Wylie

s.wylie@murdoch.edu.au

1 Plant Biotechnology Research Group (Plant Virology), Western Australian State Agricultural Biotechnology Centre, School of Veterinary and Life Sciences, Murdoch University, Perth, WA 6150, Australia symptoms on some experimentally-infected plants suggested that wild infected plants may be difficult to identify from symptoms alone (Wylie et al., 2015). Here, a survey for YTMMV was undertaken of asymptomatic and symptomatic solanaceous and other indigenous plants from across a large geographical area of coastal Western Australia. The aim of the survey was to provide a greater understanding of the distribution and natural host range of YTMMV.

\section{Sample collection}

Leaf samples from 89 specimens of 14 species were collected from road and track verges along a broad coastal strip extending from Maud's Landing near Coral Bay in the subtropical zone, to Esperance in the temperate zone of Western Australia in 2015 (Fig. 1, Table 1). Samples were collected individually into polythene zip lock bags and sealed to prevent cross contamination. Plants with virus-like symptoms were collected when present (Table 1), otherwise most sampled plants appeared symptomless. Plant samples were collected under a flora licence issued by the Western Australian Department of Parks and Wildlife (DPAW), and after permission was gained from local offices of DPAW.

Approximately $1 \mathrm{~g}$ of each leaf sample collected was ground in phosphate buffer and used to manually inoculate two seedlings of $N$. benthamiana accession RA4 as described (Wylie et al., 2015). Responses to infection were recorded from 1 to 4 weeks post inoculation. Total nucleic acids were extracted from $100 \mathrm{mg}$ of leaf tissue from each sample collected and enriched for dsRNA using a cellulose-based method (Morris, 1979) modified by replacing Whatman CF11 cellulose powder with Machery-Nagel MN100 cellulose powder. Samples were screened for YTMMV using virus-specific primers in RT-PCR assays. The MyTaq ${ }^{\mathrm{TM}}$ One-Step RT-PCR system (Bioline) was used to synthesise cDNA and amplify 


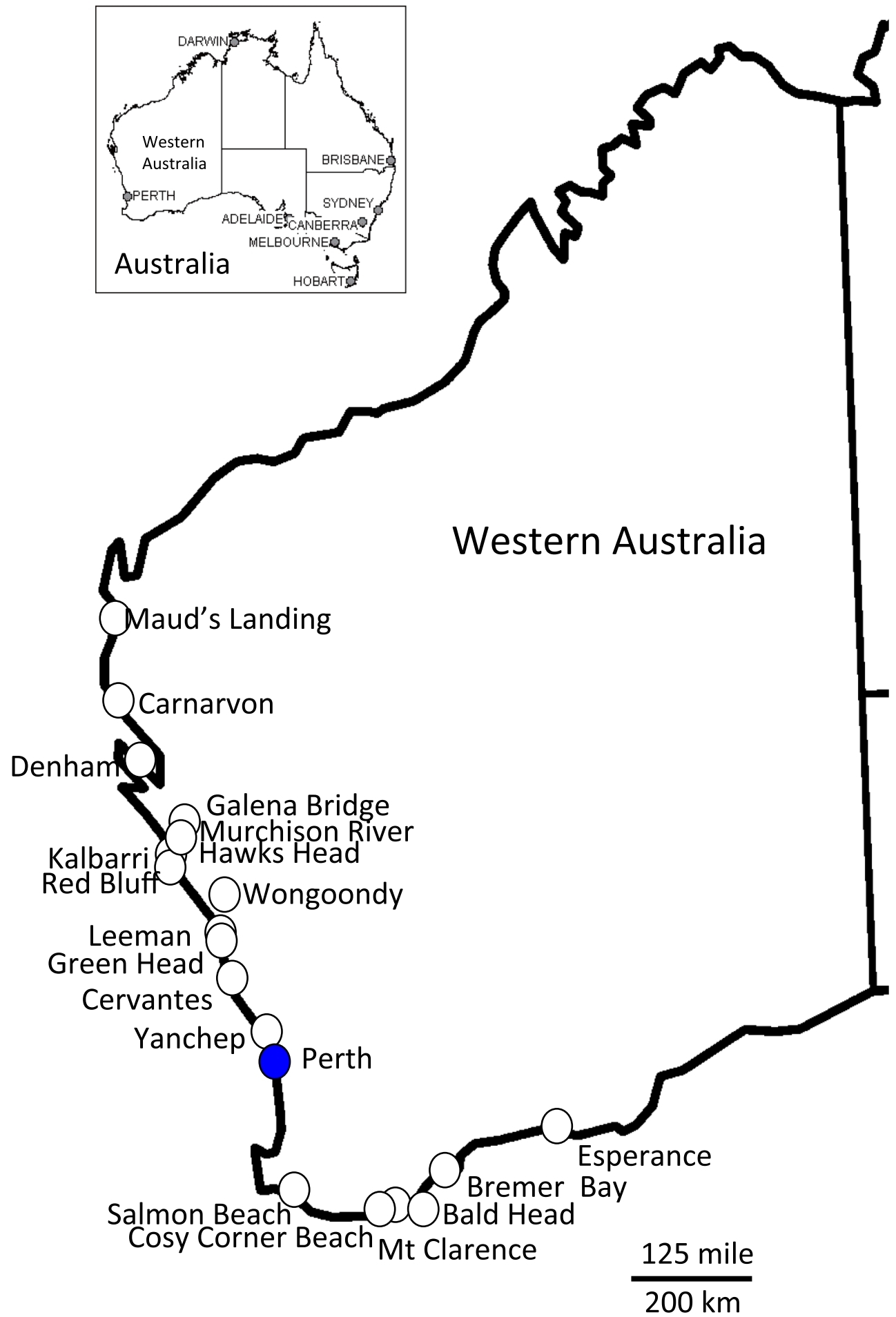

Fig. 1 Sites in Western Australia where plant samples were collected and shown to be infected with yellow tailflower mild mottle virus. Collection sites are shown as circles

fragments of virus genomes in the presence of virus-specific forward and reverse primers. Virus-specific primers were designed from complete genome sequences of YTMMVKalbarri (GenBank Accession KJ683937) and YTMMVCervante (KF495564). YTMMV-specific primers annealed within the replicase gene of YTMMV. Primers
YTMMV461F 5'-GATGTTCGTGACGTCATGCG-3' and YTMMV809R 5'-TAGCGGGTAACTCCACGGTA-3' generated an amplification product of $348 \mathrm{nt}$, and this was sequenced in both directions using the virus-specific primers described above. Sequence analysis was done after trimming sequences of primers. Alignment was done using ClustalW 
Table 1 Plants tested for the presence of yellow tailflower mild mottle virus, their collection sites in Western Australia, and accession codes of partial YTMMV replicase genes

\begin{tabular}{|c|c|c|c|c|c|}
\hline Plant species & $\begin{array}{l}\text { Collection site/ } \\
\text { YTMMV isolate name }\end{array}$ & GPS coordinates & $\begin{array}{l}\text { YTMMV assay } \\
\text { results. Sequence }^{\text {a }}\end{array}$ & $\begin{array}{l}\text { Virus-like symptoms } \\
\text { present on host? }\end{array}$ & $\begin{array}{l}\text { Sequence } \\
\text { accession }\end{array}$ \\
\hline $\begin{array}{l}\text { Anthocercis gracilis } \\
\text { A. gracilis }\end{array}$ & $\begin{array}{l}\text { Yanchep } 1 \\
\text { Yanchep } 2\end{array}$ & $\begin{array}{l}-31.546437,115.677100 \\
-31.546437,115.677100\end{array}$ & $\begin{array}{l}\text { Positive + Sequence } \\
\text { Positive }\end{array}$ & & MF177186 \\
\hline A. ilicifolia subsp. ilicifolia & Red Bluff 1 & $-27.744972,114.142830$ & Positive + Sequence & Yes & MF177187 \\
\hline A. ilicifolia subsp. ilicifolia & Red Bluff 2 & $-27.744972,114.142830$ & Positive + Sequence & Yes & MF177188 \\
\hline A. littorea & Denham & $-26.068617,113.609558$ & Positive + Sequence & & MF177218 \\
\hline A. littorea & Kalbarri & $-27.712636,114.157162$ & Positive + Sequence & & MF177193 \\
\hline A. littorea & Green Head 3 & $-30.064650,114.965201$ & Positive + Sequence & & MF177192 \\
\hline A. littorea & Leeman & $-29.947107,114.975382$ & Positive + Sequence & & MF177194 \\
\hline A. littorea & Cervantes 1 & $-30.601607,115.149816$ & Positive + Sequence & & MF177184 \\
\hline A. littorea & Cervantes 2 & $-30.601607,115.149816$ & Positive + Sequence & & MF177189 \\
\hline A. littorea & Cervantes 3 & $-30.601607,115.149816$ & Positive + Sequence & & MF177190 \\
\hline A. viscosa & Cosy Corner Beach 1 & $-35.059798,117.646330$ & Positive + Sequence & & MF177207 \\
\hline A. viscosa & Cosy Corner Beach 2 & $-35.059798,117.646330$ & Positive + Sequence & & MF177208 \\
\hline A. viscosa & Cosy Corner Beach & $-35.059798,117.646330$ & Positive & & \\
\hline A. viscosa & Cosy Corner Beach 3 & $-35.059798,117.646330$ & Positive + Sequence & & MF177209 \\
\hline A. viscosa & Cosy Corner Beach & $-35.059798,117.646330$ & Negative & & \\
\hline A. viscosa & Cosy Corner Beach & $-35.059798,117.646330$ & Negative & & \\
\hline A. viscosa & Cosy Corner Beach & $-35.059798,117.646330$ & Negative & & \\
\hline A. viscosa & Cosy Corner Beach & $-35.059798,117.646330$ & Negative & & \\
\hline A. viscosa & Cosy Corner Beach & $-35.059798,117.646330$ & Negative & & \\
\hline A. viscosa & Cosy Corner Beach & $-35.059798,117.646330$ & Negative & & \\
\hline A. viscosa & Mt Clarence 1 & $-35.025462,117.896267$ & Positive + Sequence & & MF177210 \\
\hline A. viscosa & Mt Clarence 2 & $-35.025462,117.896267$ & Positive + Sequence & & MF177211 \\
\hline A. viscosa & Mt Clarence & $-35.025462,117.896267$ & Negative & & \\
\hline A. viscosa & Mt Clarence & $-35.025462,117.896267$ & Negative & & \\
\hline A. viscosa & Mt Clarence & $-35.025462,117.896267$ & Negative & & \\
\hline A. viscosa & Mt Clarence & $-35.025462,117.896267$ & Negative & & \\
\hline A. viscosa & Mt Clarence & $-35.025462,117.896267$ & Negative & & \\
\hline A. viscosa & Mt Clarence & $-35.025462,117.896267$ & Negative & & \\
\hline A. viscosa & Mt Clarence & $-35.025462,117.896267$ & Negative & & \\
\hline A. viscosa & Mt Clarence & $-35.025462,117.896267$ & Negative & & \\
\hline A. viscosa & Mt Clarence & $-35.025462,117.896267$ & Negative & & \\
\hline A. viscosa & Mt Clarence & $-35.025462,117.896267$ & Negative & & \\
\hline A. viscosa & Mt Clarence & $-35.025462,117.896267$ & Negative & & \\
\hline A. viscosa & Mt Clarence 3 & $-35.025462,117.896267$ & Positive + Sequence & & MF177212 \\
\hline A. viscosa & Mt Clarence & $-35.025462,117.896267$ & Positive & & \\
\hline A. viscosa & Mt Clarence & $-35.025462,117.896267$ & Negative & & \\
\hline A. viscosa & Mt Clarence & $-35.025462,117.896267$ & Positive & & \\
\hline A. viscosa & Mt Clarence & $-35.025462,117.896267$ & Negative & & \\
\hline A. viscosa & Mt Clarence & $-35.025462,117.896267$ & Positive & & \\
\hline A. viscosa & Mt Clarence & $-35.025462,117.896267$ & Positive & & \\
\hline A. viscosa & Bald Head 1 & $-35.103047,118.013625$ & Positive + Sequence & & MF177195 \\
\hline A. viscosa & Bald Head & $-35.103047,118.013625$ & Negative & & \\
\hline A. viscosa & Bald Head & $-35.103047,118.013625$ & Negative & & \\
\hline A. viscosa & Bald Head & $-35.103047,118.013625$ & Negative & & \\
\hline A. viscosa & Bald Head & $-35.103047,118.013625$ & Negative & & \\
\hline A. viscosa & Bald Head & $-35.103047,118.013625$ & Negative & & \\
\hline A. viscosa & Bald Head & $-35.103047,118.013625$ & Negative & & \\
\hline A. viscosa & Bald Head 2 & $-35.103047,118.013625$ & Positive + Sequence & & MF177196 \\
\hline A. viscosa & Bald Head 3 & $-35.103047,118.013625$ & Positive + Sequence & & MF177197 \\
\hline A. viscosa & Bald Head 4 & $-35.103047,118.013625$ & Positive + Sequence & & MF177198 \\
\hline A. viscosa & Bald Head & $-35.103047,118.013625$ & Positive & & \\
\hline A. viscosa & Bald Head & $-35.103047,118.013625$ & Positive & & \\
\hline A. viscosa & Bald Head & $-35.103047,118.013625$ & Positive & & \\
\hline A. viscosa & Bald Head & $-35.103047,118.013625$ & Positive & & \\
\hline A. viscosa & Bremer Bay 1 & $-34.397249,119.391834$ & Positive + Sequence & & MF177199 \\
\hline A. viscosa & Bremer Bay 2 & $-34.397249,119.391834$ & Positive + Sequence & & MF177200 \\
\hline A. viscosa & Bremer Bay 3 & $-34.397249,119.391834$ & Positive + Sequence & & MF177201 \\
\hline A. viscosa & Bremer Bay 4 & $-34.397249,119.391834$ & Positive + Sequence & & MF177202 \\
\hline A. viscosa & Bremer Bay 5 & $-34.397249,119.391834$ & Positive + Sequence & & MF177203 \\
\hline A. viscosa & Bremer Bay 6 & $-34.397249,119.391834$ & Positive + Sequence & & MF177204 \\
\hline A. viscosa & Bremer Bay 7 & $-34.397249,119.391834$ & Positive + Sequence & & MF177205 \\
\hline A. viscosa & Bremer Bay 8 & $-34.397249,119.391834$ & Positive + Sequence & & MF177206 \\
\hline A. viscosa & Bremer Bay & $-34.397249,119.391834$ & Positive & & \\
\hline
\end{tabular}


Table 1 (continued)

\begin{tabular}{|c|c|c|c|c|c|}
\hline Plant species & $\begin{array}{l}\text { Collection site/ } \\
\text { YTMMV isolate name }\end{array}$ & GPS coordinates & $\begin{array}{l}\text { YTMMV assay } \\
\text { results. Sequence }^{a}\end{array}$ & $\begin{array}{l}\text { Virus-like symptoms } \\
\text { present on host? }\end{array}$ & $\begin{array}{l}\text { Sequence } \\
\text { accession }\end{array}$ \\
\hline A. viscosa & Bremer Bay & $-34.397249,119.391834$ & Positive & & \\
\hline A. viscosa & Esperance & $-33.877767,121.881718$ & Positive + Sequence & & MF177185 \\
\hline A. littorea & Denham & $-25.991455,113.576289$ & Positive + Sequence & & MF177191 \\
\hline Capsicum annuum & Carnarvon 1 & $-24.826038,113.765729$ & Positive + Sequence & Yes & MF177213 \\
\hline C. аппиит & Carnarvon 2 & $-24.826038,113.765729$ & Positive + Sequence & Yes & MF177214 \\
\hline Cuscuta epithymum (infecting $S$. lasiophyllum) & Galena Bridge & $-27.827557,114.688613$ & Negative & & \\
\hline Datura inoxia & Murchison River & $-27.553673,114.448189$ & Negative & & \\
\hline Hardenbergia comptoniana & Green Head 3 & $-30.064650,114.965201$ & Negative & & \\
\hline Solanum species & Green Head 2 & $-30.064650,114.965201$ & Negative & & \\
\hline N. occidentalis subsp. obliqua & Murchison River & $-27.811318,114.474513$ & Negative & & \\
\hline N. occidentalis subsp. obliqua & Murchison River 1 & $-27.811318,114.474513$ & Positive + Sequence & Yes & MF177215 \\
\hline N. occidentalis subsp. obliqua & Murchison River 2 & $-27.553673,114.448189$ & Positive + Sequence & Yes & MF177216 \\
\hline Nicotiana. occidentalis subsp. obliqua & Murchison River 3 & $-27.553673,114.448189$ & Positive + Sequence & Yes & MF177217 \\
\hline N. rotundifolia & Murchison River 4 & $-27.789319,114.469601$ & Negative & & \\
\hline Solanum lasiophyllum & Denham & $-25.991455,113.576289$ & Positive & & \\
\hline S. lasiophyllum & Galena Bridge & $-27.827557,114.688613$ & Negative & & \\
\hline S. lasiophyllum & Maud's Landing & $-23.176355,113.765933$ & Positive & & \\
\hline S. nigrum & Salmon Beach 1 & $-34.814098,116.004261$ & Negative & & \\
\hline S. nigrum & Salmon Beach 2 & $-34.814098,116.004261$ & Negative & & \\
\hline S. nigrum & Hawks Head 1 & $-27.789319,114.469601$ & Negative & & \\
\hline S. oldfieldii & Hawks Head 2 & $-27.789319,114.469601$ & Positive & & \\
\hline Solanum species & Hawks Head & $-27.789319,114.469601$ & Negative & & \\
\hline Solanum species & Green Head 1 & $-30.064650,114.965201$ & Positive + Sequence & & MF177219 \\
\hline Solanum species & Green Head 2 & $-30.064650,114.965201$ & Positive + Sequence & & MF177220 \\
\hline Solanum species & Wongoondy & $-28.917225,115.440891$ & Positive + Sequence & & MF177221 \\
\hline
\end{tabular}

${ }^{\text {a }}$ Positive, presence of YTMMV determined by RT-PCR. Positive + Sequence, presence of YTMMV determined by RT-PCR and confirmed by Sanger sequencing

(Thompson et al., 2002), and phylogenetic analysis was done in Mega 7 software (Kumar et al., 2016) using the Neighborjoining method.

Of the 14 species tested, at least one specimen of eight known solanaceous species and one unidentified indigenous species of Solanum were found to be naturally infected with YTMMV (Table 1). Plants of Nicotiana occidentalis subsp. obliqua, Anthocercis gracilis, and Capsicum annuum exhibited virus-like symptoms, while the rest appeared asymptomatic. Presence of YTMMV was confirmed by the occurrence of the typically severe symptoms of YTMMV infection on inoculated plants of $N$. benthamiana, by RT-PCR products generated from the original leaf samples and from the experimentallyinoculated $N$. benthamiana plants using YTMMV-specific primers, and by sequence analysis of most RT-PCR products (Table 1). Infected plants were of the following species: Anthocercis littorea (7/7 plants tested), A. ilicifolia subsp. ilicifolia (2/2 plant tested), A. gracilis (2/2 plants tested), A. viscosa (21/46 plants tested), Nicotiana occidentalis subsp. obliqua (3/4 plants tested), Solanum lasiophyllum (2/3 plants tested), $S$. oldfieldii (1/1 plant tested), an unidentified species of Solanum (3/4 plants tested), and Capsicum annuum (2/2 plants tested) (Table 1). The two most geographically distant sites where YTMMV was found were Maud's Landing near the township of Coral Bay, and the township of Esperance, located approximately $1500 \mathrm{~km}$ apart (Fig. 1).
YTMMV was previously reported from A. littorea and A. ilicifolia subsp. ilicifolia (Wylie et al., 2014; Li et al., 2016) from coastal sites. In this study, YTMMV was detected from two further species of Anthocercis: A. viscosa and A. gracilis. A. viscosa naturally occurs along several hundred $\mathrm{km}$ of the southern coast. This species was widely infected with YTMMV; almost half of the A. viscosa samples collected being infected asymptomatically. A. gracilis has a more restricted natural distribution, being confined to near the Perth metropolitan area. Both A. gracilis plants tested exhibited typical virus-like symptoms of yellowing young leaves, but Koch's postulates were not done to determine if chlorosis is a symptom of YTMMV infection in this species. Three of the four plants of $N$. occidentalis ssp. obliqua tested were infected with YTMMV, and all three infected plants exhibited typical virus-like symptoms of stunting, leaf distortion, chlorosis and mottling patterns. Experimentally-inoculated plants of the three subspecies of $N$. occidentalis exhibited similar severe symptoms in response to YTMMV infection (Wylie et al., 2015). Two plants of Capsicum annuum collected from a vegetable farm near Carnarvon were naturally infected with YTMMV and exhibited mild symptoms of virus infection, similar to those observed on some experimentally inoculated cultivars of this species (Wylie et al., 2015). None of the non-solanaceous plants tested were infected with YTMMV. 
RT-PCR products from most of the samples were sequenced to confirm they originated from YTMMV. Alignment and phylogenetic analysis of the sequences revealed that the isolates fell into two clades (Fig. 2). In general, the isolates collected from sites to the north of Perth city fell into clade 1 , and those from the south fell

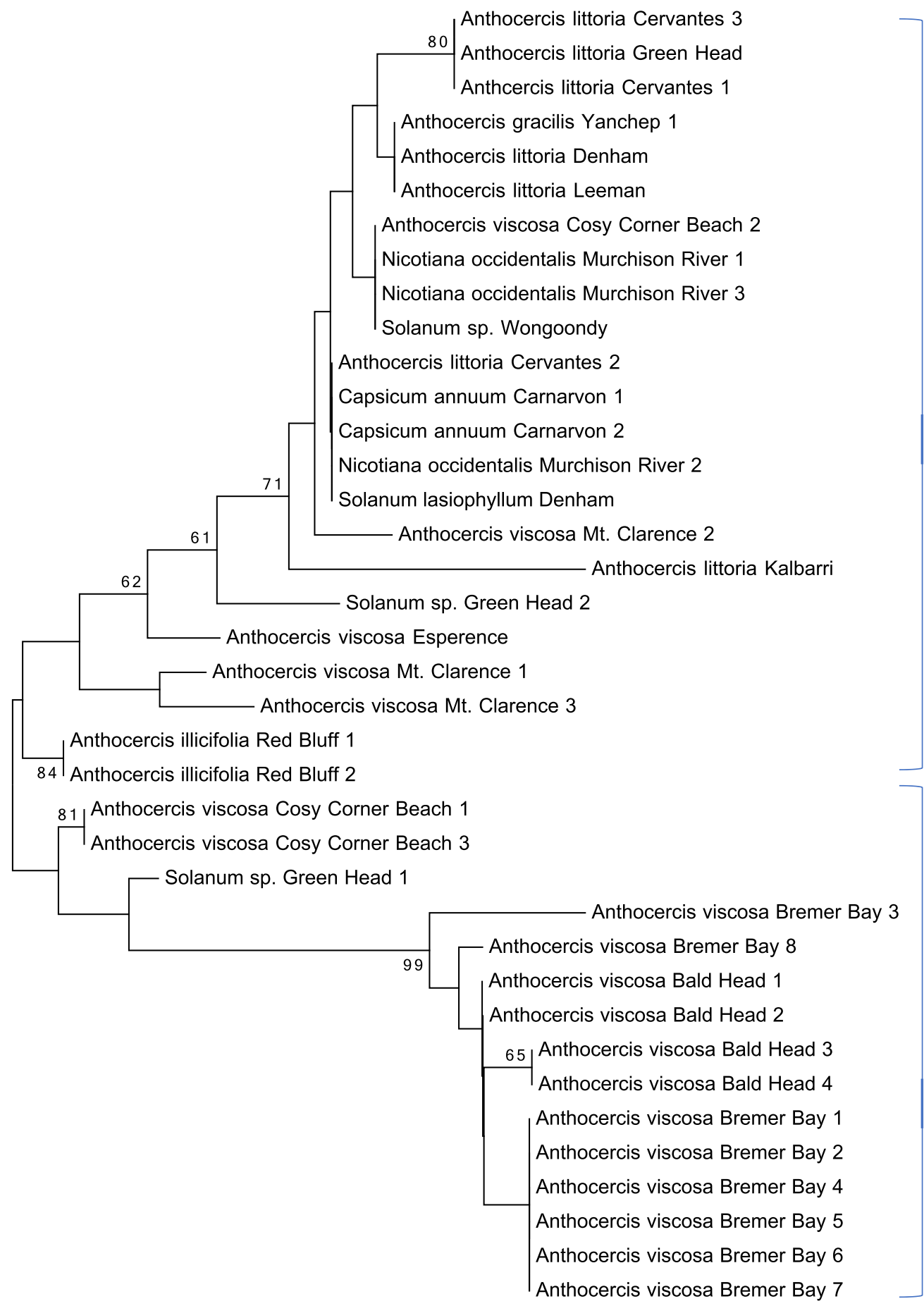

Clade 1

Clade 2

$$
\stackrel{\vdash}{0.005}
$$

Fig. 2 Estimated phylogeny of partial replicase genes of isolates of yellow tailflower mild mottle virus. Shown are the host species from which the isolate was collected, followed by the isolate name. The tree was deduced in Mega v7.0.21 after alignment in ClustalW using the
Neighbor-joining method with 1000 bootstrap replications. Bootstrap support for branches is shown at the junctions of branches where it was $>60 \%$. Branch lengths are proportional to genetic distance in units of nucleic acid substitutions per site 
into clade 2, with a few exceptions. Three isolates from Mt. Clarence and one from Cosy Corner beach located near Albany in the south appeared as atypical members of clade 1, and an isolate from Green Head grouped with southern isolates in clade 2 .

YTMMV occurred across a far greater geographical area than was previously recognised. It was detected along the coastal district from Maud's Landing near the town of Coral Bay, located within the subtropical zone of Western Australia, to Esperance, located in its temperate zone. The virus was present in four species of Anthocercis, a genus comprising nine perennial species endemic to south western Australia (Haegi, 1986). Its natural host range was extended to indigenous species in Nicotiana (annual species) and Solanum (annual and perennial species). It is probable that YTMMV naturally infects other species of the approximately 192 indigenous, cultivated and naturalised exotic solanaceous species described from Western Australia, a region of global floral biodiversity (Hopper and Gioia, 2004). Many of the indigenous solanaceous species present in the State are desert plants, and these regions have yet to be surveyed for YTMMV. These results supported the findings of an earlier experimental host range study that showed YTMMV to be capable of systemically or locally infecting all of the indigenous and exotic solaneaceous species tested (Li et al., 2016).

This is the first report of 'spillover' of YTMMV from the indigenous flora to an exotic species, in this case to two plants collected from a commercial crop of bell pepper (C. anпиит) located near the town of Carnarvon. The vegetable farm is located adjacent to natural vegetation where indigenous solanaceous plants occur, including species of Solanum, Physalis, Nicotiana and Anthocercis. It seems likely that the original source of the virus was the indigenous solanaceous plants growing nearby, although this was not tested. It remains to be seen whether YTMMV will become a pathogen of concern to solanaceous vegetable growers.

Non-solanaceous plants were not infected. This is not surprising because other solanaceae-infecting tobamoviruses do not systemically infect hosts outside the family (Stobbe et al., 2012).

YTMMV isolates were genetically differentiated into a northern and a southern group, although there was some mixing that indicates the two groups are not completely isolated from one another. Sequencing a greater proportion of the genomes of geographically separated isolates may provide more information on how fast these genomes evolve and how genotypes spread. YTMMV and other tobamoviruses do not have specific anthropod vectors, instead their famously resilient virions are sometimes transmitted in pollen, and/or by physical contact between plants, by animal contact, and by human activities. Dried leaves from infected plants may also act as vehicles in which tobamoviruses are spread over long distances on air currents (Sarra et al., 2004).

The survey reported here was not designed to comprehensively assess occurrence of YTMMV across all solanaceous species in the study region. Only 89 samples were collected from 14 species over a large area. Of these, 43 plants were infected with the virus, in most cases asymptomatically. The surprisingly large proportion of infected plants suggests that this tobamovirus occurs commonly in wild solanaceous plants of the region. Its occurrence in two capsicum plants in a horticultural holding is the first evidence that YTMMV is transmitted naturally from indigenous to exotic species. If it is also transmitted naturally to other crops, such as tomato where expressed symptoms are very mild, the virus could be carried inadvertently in seedlings or fruit to new locations. Although symptoms of YTMMV infection are usually mild, in some species and varieties they are severe (Wylie et al., 2015). Studies on yield losses caused by YTMMV infection in solanaceous crop plants have not been done.

Acknowledgements This research was funded in part by a Murdoch University small research grant.

\section{References}

Haegi L (1986) The affinities of Anthocercis (Solanaceae) and related genera, in: D'Arcy. Biology and Systematics. Columbia University Press, New York, W. G., Solanaceae, pp 27-40

Hopper SD, Gioia P (2004) The southwest Australian floristic region: evolution and conservation of a global hot spot of biodiversity. Annu Rev Ecol Evol Syst 35:623-650

Kumar S, Stecher G, Tamura K (2016) MEGA7: molecular evolutionary genetics analysis version 7.0 for bigger datasets. Mol Biol Evol 33: 1870-1874

Li H, Zhang C, Luo H, Jones MGK, Sivasithamparam K, Koh SH, Ong JWL, Wylie SJ (2016) Yellow tailflower mild mottle virus and pelargonium zonate spot virus co-infect a wild plant of red-striped tailflower in Australia. Plant Pathol 65:503-509

Morris TJ (1979) Isolation and analysis of double-stranded RNA from virus-infected plant and fungal tissue. Phytopathology 69(8):854

Sarra S, Oevering P, Guindo S, Peters D (2004) Wind-mediated spread of rice yellow mottle virus (RYMV) in irrigated rice crops. Plant Pathol 53:148-153

Stobbe AH, Melcher U, Palmer MW, Roossinck MJ, Shen G (2012) Codivergence and host-switching in the evolution of tobamoviruses. J Gen Virol 93:408-418

Thompson JD, Gibson TJ, Higgins DG, 2002. Multiple sequence alignment using ClustalW and ClustalX. Current Protocols in Bioinformatics. 00:2.3:2.3.1-2.3.22

Wylie SJ, Li H, Jones MGK (2014) Yellow tailflower mild mottle virus: a new tobamovirus described from Anthocercis littorea (Solanaceae) in Western Australia. Arch Virol 159:791-795

Wylie SJ, Zhang C, Long V, Roossinck M, Koh SH, Jones MGK, Iqbal S, Li H (2015) Differential responses to virus challenge of laboratory and wild accessions of Australian species of Nicotiana, and comparative analysis of RDR1 gene sequences. PLoS One. doi:10.1371/ journal.pone. 0121787 